\title{
PEMBERDAYAAN GURU DALAM PENGEMBANGAN PERANGKAT PEMBELAJARAN IPA SMP TAHAP LESSON PLAN DALAM SISTIM LSLC
}

\author{
Yanti Rosinda Tinenti*,Anselmus Boy Baunsele, Hildegardis Missa, \\ Hironimus Tangi \\ Fakultas MIPA, Universitas Katolik Widya Mandira \\ email: yantitinenti@gmail.com
}

\begin{abstract}
This PKM is conducted at Sint Vianney Middle School which is located at JLN. I Gusti Ngurah Rai, Kampung Baru Village, Soe City District, TTS Regency, NTT Province. The resulting target is an increase in the ability of teachers to design learning devices that meet the standards of the learning process, improvement in the ability of teachers to develop assessment instruments for aspects of knowledge (KI 3) that include high order thinking skills (High Order Thingking Skill / HOT), skills (KI 4 ), and optimizing the use of practical tools and materials in schools and the surrounding environment in the process of developing learning tools. Activities that have been carried out to achieve the above PKM targets consist of a lesson plan phase in the Lesson Study Learning Community (LSLC) system, namely:

1. Planning the PKM activity schedule with the team leader, members and teachers in the school.

2. Seminar on the implementation of the LSLC system, development of learning tools, and assessment instruments that meet the process standards and assessment standards in the 2013 curriculum.

3. Lesson plan in the Lesson Study Learning Community (LSLC) system.
\end{abstract}

Keywords: Lesson Plan, LSLC, High Order Thingking

\begin{abstract}
Abstrak
PKM ini dilakukan di SMPK Sint Vianney yang beralamat di JLN. I Gusti Ngurah Rai, Kelurahan Kampung Baru, Kecamatan Kota Soe Kabupaten TTS, Provinsi NTT. Target yang dihasilkan yakni peningkatan kemampuan guru dalam merancang perangkat pembelajaran yang memenuhi standar proses pembelajaran, peningkatan kemampuan guru dalam mengembangkan instrumen penilaian untuk aspek pengetahuan (KI 3) yang mencakup kemampuan berpikir tingkat tinggi (High order Thingking Skill/HOT), keterampilan (KI 4), dan optimalisasi penggunaan alat dan bahan praktikum di sekolah maupun di lingkungan sekitar dalam proses pengembangan perangkat pembelajaran. Kegiatan yang telah dilakukan untuk mencapai target PKM di atas terdiri dari tahap perencanaan (lesson plan) pada sistim Lesson Study Learning Community (LSLC), yakni:

1. Perencanaan jadwal kegiatan PKM bersama ketua tim, anggota dan guru-guru di sekolah.

2. Seminar tentang pelaksanaan sistem LSLC, pengembangan perangkat pembelajaran, dan instrumen penilaian yang memenuhi standar proses dan standar penilaian dalam kurikulum 2013.

3. Tahap Perencanaan (lesson plan) pada sistim Lesson Study Learning Community (LSLC).
\end{abstract}

Kata Kunci : Lesson Plan, LSLC, High Order Thingking.

\section{PENDAHULUAN}

Kabupaten Timur Tengah Selatan (TTS) dengan ibu kota Soe, merupakan salah satu kabupaten di NTT dengan tingkat pencapaian pendidikan yang masih berada di bawah standar. Hal ini 
didukung dengan data perolehan nilai Ujian Nasional (UN) untuk tingkat SMP/MTS, pada 151 sekolah, tahun 2018 yang dihimpun dari Dinas Pendidikan Pemuda dan Olahraga (PPO) Kabupaten TTS. Data tersebut dapat diungkapkan bahwa dari 151 sekolah hanya terdapat 21 atau $22,90 \%$ sekolah yang memperoleh nilai rata-rata $\mathrm{UN}$ untuk semua mata pelajaran pada rentangan nilai 70-85. Sedangkan sebanyak 130 atau $77,1 \%$ sekolah masih memperoleh nilai rata-rata di bawah 60 . Khusus untuk mata pelajaran IPA hanya terdapat 18 atau $11,91 \%$ sekolah yang memperoleh nilai rata-rata UN pada rentangan nilai 70-85. Sedangkan sebanyak 133 atau 88,09\% sekolah masih memperoleh nilai rata-rata di bawah 60 .

IPA/sains adalah suatu ilmu empiris yang didasari atas pengamatan dan eksperimen (percobaan), dengan demikian agar pengamatan dan eksperimen (percobaan) sebagai bagian integral dalam pendidikan sains dapat berjalan dengan baik, maka diperlukan sebuah laboratorium dan proses manajemen/pengelolaan yang baik. Namun berdasarkan hasil observasi ditemukan bahwa di sekolah mitra tidak terdapat ruangan khusus sebagai laboratorium. Meskipun tidak terdapat ruangan khusus sebagai laboratorium namun terdapat alat dan bahan yang dapat mendukung terlaksananya proses pengamatan dan eksperimen (percobaan) dalam pembelajaran IPA namun diletakkan di ruangan kelas.

Selain laboratorium, disyaratkan pula standar proses pendidikan yang mencakup aspek-aspek dalam pendekatan saintifik pada kurikulum 2013, khususnya pada mata pelajaran sains/IPA SMP. Hal ini sejalan dengan yang diungkapkan dalam Peraturan Menteri Pendidikan Dan Kebudayaan Nomor 22 Tahun 2016 Tentang Standar Proses Pendidikan Dasar dan Menengah yang mensyaratkan penggunaan pendekatan ilmiah (scientific), untuk mendorong kemampuan peserta didik dalam menghasilkan karya kontekstual, baik individual maupun kelompok. Agar hal ini tercapai maka sangat disarankan menggunakan pendekatan pembelajaran yang menghasilkan karya berbasis pemecahan masalah (project based learning).

Berdasarkan hasil observasi di temukan bahwa pelaksanaan kegiatan pembelajaran IPA yang belum memenuhi standar proses tersebut berdampak pada tingkatan pengetahuan yang diajarkan kepada siswa. Tingkatan pengetahuan yang diajarkan hanya sebatas keterampilan dan pengetahuan tingkat rendah serta belum mencakup keterampilan berpikir tingkat tinggi (High order Thingking Skill/HOT). Keterampilan berpikir tingkat tinggi, hanya bisa terpenuhi apabila selama proses pembelajaran guru mampu menyediakan kondisi yang mampu membuat siswa berpikir secara maksimal.

\section{METODE PENGABDIAN}

Adapun program yang dilakukan terdiri dari tahapan kegiatan sebagai berikut:

1. Perencanaan jadwal kegiatan PKM bersama ketua tim, anggota dan guru-guru di sekolah.

2. Seminar tentang pelaksanaan sistem LSLC, Pengembangan Perangkat Pembelajaran, dan instrumen penilaian yang memenuhi standar proses dan standar penilaian dalam kurikulum 2013. Dalam seminar ini materi yang dipresentasikan dan didiskusikan antara lain
a. Penggunaan sistem $L S L C$ dibawakan oleh Kepala LP3M Universitas Katolik Widya Mandira (UNWIRA). 
b. Pengembangan Lembar kegiatan peserta didik (LKPD) dan model, pendekatan, yang memenuhi standar proses pembelajaran menurut kurikulum 2013.

c. Pengembangan instrumen penilaian aspek keterampilan yang memenuhi standar penilaian kurikulum 2013 dan bagaimana mengintegrasikannya dalam proses pembelajaran di kelas.

d. Pengembangan intrumen penilaian aspek pengetahuan yang merujuk pada kemampuan berpikir tingkat tinggi/ hight order thingking (HOT). Dibawakan oleh ketua tim dan anggota PKM.

3. Tahap Perencanaan (lesson plan) pada sistim Lesson Study Learning Community (LSLC). Pada tahap ini guru IPA yang terdiri dari 2 orang guru fisika dan 3 orang guru biologi di himpun untuk mengidentifikasi masalah dalam proses pembelajaran dan melakukan perencanaan melalui kegiatan:

a. Workshop Pengembangan Lembar Kegiatan Peserta Didik (LKPD) materi sains/IPA SMP dan pengembangan instrumen keterampilan (KI 4)

b. Workshop pengembangan Rencana Pelaksanaan

Pembelajaran (RPP) yang sesuai standar proses pembelajaran.

c. Workshop pengembangan instrumen penilaian aspek pengetahuan (KI 3) yang merujuk pada keterampilan berpikir tingkat tinggi/hight order thingking (HOT)

Pengembangan perangkat pembelajaran dalam Workshop ini dipandu oleh ketua dan anggota tim PKM. dilakukan pada bulan Maret sampai dengan Mei 2019.

\section{HASIL DAN PEMBAHASAN}

Dalam bagian ini akan dikemukakan hasil dan pembahasan yang berkaitan dengan pelaksanaan kegiatan PKM.

\section{A. Seminar tentang pelaksanaan sistem LSLC, Pengembangan Perangkat Pembelajaran, dan instrumen penilaian yang memenuhi standar proses dan standar penilaian dalam kurikulum 2013.}

Kegiatan ini dilakukan pada tanggal 21 Maret 2019 bertempat di SMPK Sint Vianney Soe. Kegiatan ini melibatkan kepala sekolah dan seluruh guru di sekolah tersebut. Diawal kegiatan ini, kepala sekolah dan ketua TIM PKM membuka kegiatan PKM secara resmi. Adapun jenis kegiatan yang dilakukan dapat dikemukakan hasil dan pembahasannya secara rinci sebagai berikut.

1. Presentasi materi dan diskusi tentang penggunaan sistem $L S L C$.

Dalam seminar tentang penggunaan sistem LSLC ini, guru-guru di sekolah mitra diberikan pemahaman tentang bagaimana melakukan persiapan (Lesson Plan), pelaksanaan pembelajajaran (do), dan refleksi/evaluasi (see) dalam sistem $L S L C$.

Guru-guru diberi pemahaman bahwa Lesson study adalah suatu model pembinaan profesi pendidik dimana para pendidik akan mengkaji pembelajaran secara kolaboratif dan berkelanjutan berdasarkan prinsip-prinsip kolegialitas agar dapat meningkatkan kualitas pembelajaran dan membangun learning community. Melalui pelaksanaan Lesson Study guru akan lebih memahami permasalahan belajar para siswa. Guru secara kolaboratif akan berbagi pengalaman tentang pelaksanaan pembelajaran dengan sesama guru dalam satu kelompok/rumpun bidang ilmu atau lintas bidang ilmu. 
2. Presentasi materi dan diskusi tentang Pengembangan Lembar kegiatan peserta didik (LKPD) dan model, pendekatan, yang memenuhi standar proses pembelajaran menurut kurikulum 2013.

Materi ini bertujuan untuk memberikan pemahaman yang lebih mendalam kepada guru agar dapat menggunakan model, pendekatan, strategi, metode yang lebih bervariasi dalam mengembangkan proses pembelajaran di kelas. Dimana model, pendekatan, strategi, metode yang akan digunakan harus disesuaikan dengan karakteristik materi pembelajaran dan standar proses pembelajaran yang dicanangkan dalam Kurikulum 2013.

Berdasarkan sharing saat kegiatan ini dapat diungkapkan pula bahwa, dalam proses pembelajaran guru-guru belum dapat mengembangkan LKPD sesuai dengan model atau pendekatan yang digunakan. Menurut guru-guru, hal ini disebabkan karena alokasi waktu pembelajaran tidak akan mencukupi jika proses pembelajaran mengimplementasikan proses praktikum, dan tidak tersedianya laboratorium. Dengan demikian guruguru diberikan pemahaman dan contoh bagaimana mengembangkan perangkat pembelajaran yang sesuai dengan memanfaatkan bahan-bahan yang ada di lingkungan sekitar dan alat serta bahan praktikum yang tersedia di sekolah. Selain itu guru-gurupun diberikan pemahaman bahwa melakukan proses pembelajaran yang sesuai dengan standar proses tidak harus didalam ruangan khusus/laboratorium, namun dapat lakukan di ruang kelas, dengan terlebih dahulu membuat perangkat pembelajaran berupa RPP dan LKPD, bahan ajar serta mempersiapkan peralatan dan bahan yang dibutuhkan.

\section{Presentasi materi tentang} pengembangan instrumen penilaian aspek keterampilan yang memenuhi standar penilaian kurikulum 2013 Materi ini bertujuan memberikan pemahaman kepada guru agar dapat mengembangkan instrumen aspek keterampilan (KI 4) dan bagaimana menggunakan instrumen tersebut selama proses pembelajaran berlangsung. Adapun instrumen aspek keterampilan (KI 4) berkaitan erat dengan LKPD yang dikembangkan.

Berdasarkan sharing saat diskusi dapat diungkapkan bahwa, guru-guru sama sekali tidak pernah melakukan penilaian aspek keterampilan dengan alasan bahwa aspek keterampilan sangat sulit untuk dinilai, keterbatasan alokasi waktu saat proses pembelajaran, dan kurangnya pemahaman dan pengetahuan dalam mengembangkan instrumen penilaian keterampilan (KI 4).

Instrumen untuk menilai aspek keterampilan (KI 4) harus dikembangkan berdasarkan jenis praktikum yang digunakan dalam mengembangkan LKPD (merujuk pada tabel 3.1). Dengan demikian jenis instrumen aspek keterampilan ini dikembangkan berdasarkan model atau pendekatan yang digunakan. Instrumen penilaian aspek keterampilan (KI 4) untuk model dan pendekatan yang satu akan berbeda dengan instrumen penilaian untuk model dan pendekatan yang lainnya.

\section{Presentasi materi tentang pengembangan intrumen penilaian aspek pengetahuan yang merujuk pada kemampuan berpikir tingkat tinggi/ hight order thingking (HOT).}

Materi ini menekankan pada peningkatan pemahaman guru tentang teknik dan prosedur pengembangan instrumen penilaian aspek pengetahuan terutama yang berkaitan dengan instrumen untuk menilai keterampilan berpikir tingkat tinggi (high order thinking skill/HOTS). 
Dalam presentasi dan diskusi ini guru-guru diberikan pemahaman tentang keterampilan berpikir tingkat tinggi yang perlu dinilai dalam proses pembelajaran termasuk dalam dimensi pengetahuan metakognitif (K4) dan tergolong dalam dimensi proses kognitif menganalisis (C4), mengevaluasi (C5), dan mencipta (C6). Dimensi pengetahuan dan dimensi proses kognitif ini termasuk dalam taksonomi Bloom yang sudah direvisi (Anderson dan Krawthwoh, 2001).

Secara garis besar materi-materi yang diprensentasikan dalam seminar ini bertujuan membekali guru untuk melakukan perencanaan (Lesson Plan) pada sistem LSLC. Dokumentasi kegiatan ini dapat ditampilkan pada gambar 3.2.

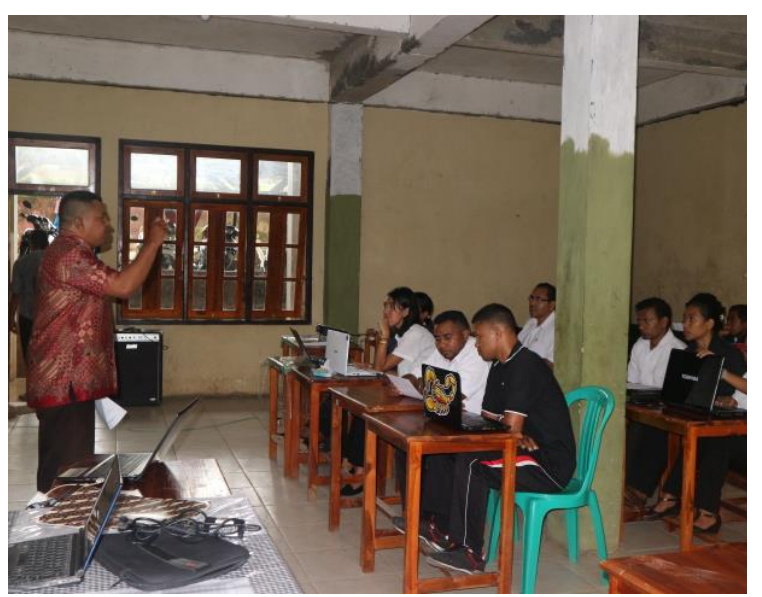

Gambar 3.2. Dokumentasi Seminar

tentang pelaksanaan sistem $L S L C$,

Pengembangan Perangkat

Pembelajaran, dan instrumen

penilaian yang memenuhi standar

proses dan standar penilaian dalam

kurikulum 2013.

B. Workshop Pengembangan Lembar

Kegiatan Peserta Didik (LKPD)

materi sains/IPA SMP dan pengembangan instrumen

keterampilan (KI 4)

Kegiatn ini dilakukan pada tanggal

27 April 2019 bertempat di sekolah mitra. Kegiatan ini merupakan tindak lanjut dari kegiatan sebelumnya berupa sosialisasi hakekat, fungsi, manfaat, dan sistematika penulisan LKPD sains/IPA kelas VII, VIII, XI. Dalam workshop ini guru sains yang terdiri dari 2 orang guru fisika, dan 3 orang guru biologi berdiskusi dalam kelompok, menentukan dan menganalisis standar kompetensi, kompetensi dasar, dan kemudian merumuskan indikator pencapaian kompetensi untuk aspek keterampilan (KI 4). Berdasarkan rumusan indikator pencapaian kompetensi aspek keterampilan tersebut, guru dalam kelompok berdiskusi untuk mengembangkan LKPD. LKPD yang dikembangkan merujuk pada pelaksanaan aspek saintifik, maupun keterampilan proses sains yang disyaratkan dalam standar proses pembelajaran.

Kegiatan-kegiatan yang dikembangkan dalam LKPD merupakan sebagian besar dari kegiatan dalam proses pembelajaran di kelas. Dengan demikian LKPD perlu dikembangkan terlebih dahulu sebelum mengembangkan rencana pelaksanaan pembelajaran (RPP). Jenis-jenis kegiatan yang akan dilakukan peserta didik dalam LKPD perlu dinilai secara menyeluruh. Dengan demikian berdasarkan LKPD yang dikembangkan maka guru dapat mengembangkan instrumen penilaian keterampilan psikomotorik untuk menilai keterlaksanaan prosedur kerja dalam LKPD. Setelah melakukan kegiatan di LKPD peserta didik akan mempresentasikan hasil kegiatan tersebut dengan demikian guru perlu mengembangkan lembar penilaian presentasi. Akhirnya peserta didik perlu melaporkan secara tertulis kegiatan yang dilakukan tesebut, dengan demikian guru perlu mengembangkan lembar penilaian laporan tertulis/portofolio.

Permasalahan yang ditemukan pada observasi awal adalah guru belum optimal dalam menggunakan alat-alat dan bahan yang tersedia di sekolah 
maupun di lingkungan sekitar sekolah dalam proses pembelajaran. Dalam perencanaan yang dilakukan secara bersama-sama untuk mengembangkan LKPD ini, guru dapat mengidentifikasi alat dan bahan yang terdapat disekolah maupun di lingkungan sekitar untuk mengembangkan LKPD. Dengan demikian dapat tercapai optimalisasi penggunaan alat dan bahan di sekolah dan di lingkungan sekitar sekolah dalam proses pembelajaran.

Rangkaian kegiatan workshop pengembangan lembar kegiatan peserta didik (LKPD) materi sains/IPA SMP dan pengembangan instrumen keterampilan (KI 4) ini masuk dalam kegiatan perencaan (Lesson Plan) yang merupakan tahap awal dari Lesson Study Learning Community (LSLC). Hasil dari kegiatan ini adalah 3 jenis LKPD dan Instrumen penilaian aspek keterampilan (KI 4) pada materi pokok tertentu (sistem interaksi makluk hidup, dan pencemaran lingkungan). Jenis LKPD pada materi pokok lainnya akan dikembangkan oleh guru dalam tim. Dokumentasi saat kegiatan ini dapat ditampilkan pada gambar 3.3

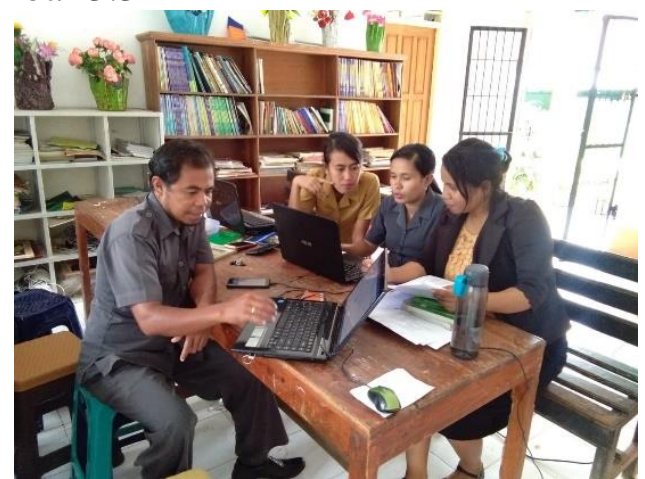

Gambar 3.3.

Dokumentasi Kegiatan Workshop

Pengembangan Lembar Kegiatan

Peserta Didik (LKPD) materi sains/IPA SMP dan

pengembangan instrumen keterampilan (KI 4)

\section{Workshop \\ Rencana \\ pengembangan \\ Pelaksanaan \\ Pembelajaran (RPP) yang sesuai standar proses pembelajaran.}

Kegiatan ini dilakukan pada tanggal 9 Mei 2019, bertempat di sekolah mitra. Kegiatan ini masih termasuk dalam tahap awal dari sistem lesson study learning community ( $L S L C$ ) yakni lesson plan. Hal yang dilakukan guru dalam tim adalah melakukan analisis karakteristik materi pokok dan kemudian memilih pendekatan dan model pembelajaran yang akan digunakan untuk mengembangkan RPP. Adapun model dan pendekatan pembelajaran yang digunakan merupakan yang dicanangkan dalam standar proses pembelajaran kurikulum 2013.

Adapun kegiatan yang dilakukan sebelumnya yakni Workshop pengembangan lembar kegiatan peserta didik (LKPD) materi sains/IPA SMP dan pengembangan instrumen aspek keterampilan (KI 4). Dengan demikian LKPD dan instrumen penilaian keterampilan yang telah dikembangkan harus diintegrasikan dalam RPP yang dikembangkan. Langkah-langkah dalam LKPD sudah dapat dijadikan acuan untuk menentukan model atau pendekatan yang akan digunakan dalam mengembangkkan RPP. Dengan demikian setelah kegiatan ini hasil yang diperoleh adalah guru dalam tim menghasilkan RPP yang mengintegrasikan LKPD dan instrumen penilaian keterampilan, serta mediamedia pembelajaran yang mendukung terlaksananya kegiatan belajar-mengajar yang memenuhi standar proses pembelajaran. Dokumentasi kegiatan ini dapat ditampilkan pada gambar 3.4 


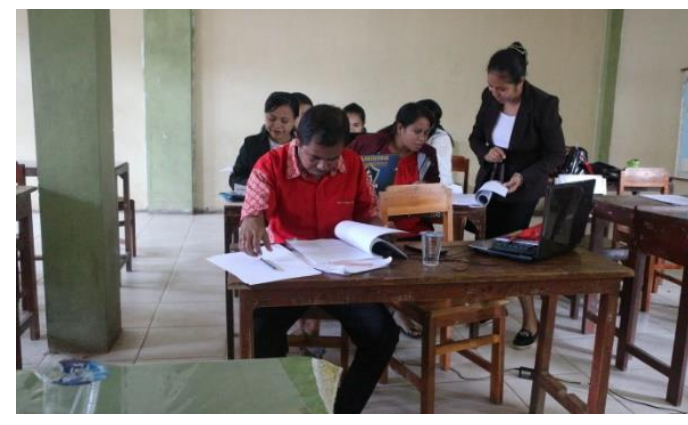

Gambar 3.4

Dokumentasi Workshop RPP

\section{Workshop pengembangan instrumen penilaian aspek pengetahuan/KI 3 yang mengacu pada keterampilan berpikir tingkat tinggi/hight order thingking (HOT)}

Dalam proses pembelajaran kita perlu melatih siswa agar memiliki kemampuan berpikir tinggi. Salah satu permasalahan yang ditemukan di sekolah mitra adalah guru-guru belum maksimal mengajarkan kemampuan berpikir tinggi selama proses pembelajaran. Dengan demikian hal ini tidak dapat dinilai di akhir proses pembelajaran.

Dalam Workshop sebelumnya yakni pengembangan RPP, LKPD, dan instrumen penilaian aspek keterampilan (KI 4), menunjukkan bahwa kemampuan berpikir tingkat tinggi akan dilatihkan selama proses pembelajaran jika perangkat pembelajaran tersebut diimplementasikan dengan baik. Berdasarkan perangkat pembelajaran yang telah dikembangkan tersebut, maka guru dalam kelompok di arahkan untuk mengembangkan instrumen penilaian kemampuan berpikir tingkat tinggi siswa.

LKPD yang dikembangkan disesuaikan dengan model dan pendekatan pembelajaran yang digunakan dalam menyusun RPP. Salah satu LKPD yang disusun dalam workshop pengembangan LKPD bertujuan untuk mengidentifikasi zat aditif sebagai pewarna, pemanis, antioksidan, dan pengawet pada makanan kemasan. LKPD kemudian dintegrasikan dalam RPP yang dikembangkan dengan pendekatan contextual teaching and learning (CTL). Dalam LKPD terdapat wacana yang membahas masalah dalam kehidupan sehari-hari terkait dengan penggunaan pewarna, pemanis, antioksidan, dan pengawet serta bagaimana dampak negatifnya apabila dikonsumsi. Diakhir wacana ini siswa diarahkan untuk mengidentifikasi permasalah, melakukan eksperimen dan menganalisis data serta menyimpulkan. Apabila perangkat berupa LKPD yang telah diintegrasikan dalam RPP ini diimplementasikan dengan baik dalam proses pembelajaran, maka dapat diindikasikan bahwa guru telah mengajarkan keterampilan berpikir tingkat tinggi kepada siswa. Selanjutnya jika hal tersebut telah diajarkan maka dengan mudah guru dapat mengembangkan instrumen penilaian terhadap proses yang telah dilakukan.

Berdasarkan pendampingan yang dilakukan saat workshop pengembangan instrumen penilaian kemampuan berpikir tingkat tinggi ini, guru dalam kelompok telah mampu mengembangkan instrumen tersebut. Hal ini ditunjukkan dengan dihasilkannya soal-soal tes kemampuan berpikir tinggi untuk setiap standar kompetensi yang dikembangkan perangkat pembelajarannya.

Berdasarkan hasil analisis data keterlaksanaan LSLC tahap Lesson Plan maka dapat dibahas beberapa hal sebagai berikut:

1. Pada saat melakukan workshop untuk untuk mengembangkan RPP dan LKPD, terlebih dahulu guru dalam tim mendiskusikan materi yang akan di ajarkan. Materi pokok yang akan diajarkan tersebut didasarkan pada standar isi kurikulum 2013 yang direvisi tahun 
2017. Hal yang didiskusikan berkaitan dengan materi pokok ini adalah tentang bagaimana jenis materi yang akan diajarkan digolongkan kedalam jenis fakta, konsep, prinsip dan prosedur.

2. Penggolongan materi pembelajaran tersebut kemudian dijadikan dasar dalam menentukan kata kerja operasional yang terdapat dalam taksonomi Bloom. Hal ini memudahkan guru dalam tim untuk merumuskan tujuan pembelajaran, dan indikator pencapaian kompetensi untuk setiap aspek yang akan dinilai yakni aspek pengetahuan/KI 3 dan aspek keterampilan /KI 4.

3. Setelah menggolongkan materi ajar dalam fakta, konsep, prinsip, dan prosedur serta merumuskan tujuan pembelajaran dan indikator pencapaian kompetensi, guru dalam tim dengan mudah menemukan masalah kontekstual dalam kehidupan sehari-hari yang dapat dibawa dalam proses pembelajaran di kelas. Misalkan pada materi pokok "pencemaran lingkungan" guru dengan mudah menemukan masalah tentang sampah plastik yang dapat mencemari tanah, sampah organik yang tidak ditanggulangi dengan baik mengakibatkan pencemaran udara, asap kendaraan bermotor penyebab pencemaran udara. Hal-hal ini kemudian menjadi dasar dalam merancang proses pembelajaran di kelas, yang mengarahkan siswa untuk mencari berbagai solusi untuk mengurangi dampak pencemaran udara dan tanah.

4. Guru dalam tim mendiskusikan media pembelajaran yang akan digunakan agar seluruh indikator pencapaian kompetensi dapat diajar dengan baik dalam proses pembelajaran. Dengan adanya tukar pikiran antara guru yang satu dengan guru yang lain dan dengan didampingi oleh tim PKM guru-guru berhasil menetukan media pembelajaran, sumber belajar alat dan bahan yang dibutuhkan dalam perancangan proses pembelajaran.

5. Karakteristik materi dapat diketahui dengan baik ketika materi pembelajaran telah didiskusikan, digolongkan dalam fakta, prinsip, konsep, prosedur serta kedalaman materi dapat tercermin lewat perumusan tujuan pembelajaran dan indikator pencapaian kompetensi.

\section{SIMPULAN}

Dalam kegiatan PKM ini dapat disimpulkan beberapa hal sebagai berikut:

1. Guru lebih memahami permasalah dalam pembelajaran karena dalam kelompok mereka berbagi pengalaman tentang pelaksanaan pembelajaran dengan guru lain dalam satu bidang ilmu/lintas ilmu. Dengan demikian telah terjadi peningkatan akuntabilitas perencanaan proses pembelajaran yang dilakukan guru. Didasarkan pada persentasi keterlaksanaan $L S L C$ tahap lesson plan yakni $88 \%$ pada kelompok guru biologi dan $84 \%$ pada kelompok guru fisika.

2. Dalam kelompok guru dapat mengembangkan perangkat pembelajaran sesuai standar proses pembelajaran dalam hal ini RPP dan LKPD dengan memanfaatkan alat dan bahan yang tersedia di sekolah maupun dilingkungan sekitar sekolah.

3. Dalam kelompok guru dapat mengembangkan perangkat pembelajaran yang valid untuk menilai aspek keterampilan/KI 4 dan aspek pengetahuan/KI 3 yang sesuai standar kompetensi dan merujuk pada kemampuan berpikir tingkat tinggi. 


\section{UCAPAN TERIMA KASIH}

Terlaksananya program PKM ini tidak terlepas dari dukungan berbagai pihak. Oleh karena itu disampaikan terima kasih kepada:

1. Kemenristek Dikti yang telah mendanai sepenuhnya kegiatan PKM ini,

2. Kepala sekolah dan semua guru SMP Katolik Sint. Vianey Kota Soe yang telah bersedia menjadi mitra pada program PKM ini.

\section{DAFTAR PUSTAKA}

[1] Belmawa, 2017. Panduan Peningkatan Mutu Pembelajaran melalui Lesson Studi Learning Community (LSLC) di Perguruan Tinggi. Dirjen Belmawa. Jakarta

[2] Kemendikbud, 2017. Model Silabus Mata Pelajaran Sekolah Menengah Pertama/Madrasah Tsanawiyah (SMP/MTs). Jakarta.

[3] Kemenristekdikti, 2018. Pedoman Program Short Term Training On Lesson Study (stols).

[4] Kurniati, D, dkk (2016). Kemampuan Berpikir Tingkat Tinggi Siswa SMP di Kabupaten Jember dalam Menyelesaikan Soal Berstandar Pizza. Jurnal Penelitian dan Evaluasi Pendidikan. Vol 2. No. 20. Diunggah pada 1 Agustus 2019.

[5] Maison dkk, 2015. Peningkatan Aktivitas Belajar Siswa pada Materi Fisika Melalui Kegiatan lesson study di SMP 17 Kota Jambi. Jurnal Pengabdian Pada Masyarakat. Vol 30. No 4.

[6] Permendikbud RI, No 22. 2016. Tentang standar proses pendidikan dasar dan menengah.
[7] Permendikbud RI. No 23. 2016. Tentang Standar Penilaian Pendidikan .

[8] Tinenti, Y, R. 2011. Pengembangan Perangkat Model Pengajaran Langsung dan Pendekatan Keterampilan Proses yang Terintegrasi dalam Model Pembelajaran Berbasis Proyek. Artikel Seminar Nasional Universitas Patimura Ambon. 